Tersedia Online di http://journal2.um.ac.id/index.php/jmsp/

ISSN Online : 2541-4429

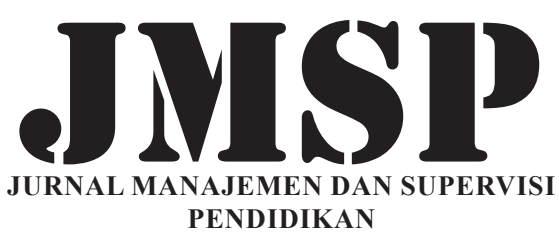

PENDIDIKAN

\title{
EVALUASI KINERJA ALUMNI DALAM MENDUKUNG PENGUATAN PROGRAM STUDI AKREDITASI
}

\author{
Arifin Suking, Megi Yusuf Hamid \\ Jurusan Manajemen Pendidikan \\ Fakultas Ilmu Pendidikan Universitas Negeri Gorontalo \\ Jalan Jenderal Sudirman No. 6 Kota Gorontalo Indonesia \\ arifin_suking@ung.ac.id
}

\begin{abstract}
This study aims to determine user satisfaction with alumni performance in terms of: (1) integrity; (2) expertise according to the field of experts; (3) ability to utilize technology; (4) communication skills; (5) ability to teamwork; and (6) self-development. This research used the quantitative study with the explanatory research type. Data collection techniques used questionnaires, interviews, observation, and documentation. The data analysis technique used is descriptive analysis technique with a percentage formula. The results showed that user satisfaction with alumni performance in terms of: (1) integrity is in the good category; (2) expertise according to the field of science is in the good category; (3) the ability to use information technology is in the good category; (4) communication skills are in the good category; (5) the ability of teamwork is in the good category; and (6) self-development is in the very good category.
\end{abstract}

\section{Keywords: Performance; Alumni; Accreditation}

\begin{abstract}
Abstrak: Penelitian ini bertujuan untuk mengetahui kepuasan pengguna terhadap kinerja alumni dalam hal: (1) integritas; (2) keahlian sesuai bidang ahli; (3) kemampuan memanfaatkan teknologi; (4) kemampuan komunikasi; (5) kemampuan kerja sama tim; dan (6) pengembangan diri. Penelitian ini merupakan penelitian kuantitatif dengan jenis penelitian eksplanatori. Teknik pengumpulan data menggunakan angket, wawancara, observasi, dan dokumentasi. Teknik analisis data yang digunakan adalah teknik analisis deskriptif dengan menggunakan formula persentase. Hasil penelitian menunjukan bahwa kepuasan pengguna terhadap kinerja alumni dalam hal: (1) integritas berada pada kategori baik; (2) keahlian sesuai bidang ilmu berada pada kategori baik; (3) kemampuan memanfaatkan teknologi informasi berada pada kategori baik; (4) kemampuan komunikasi berada pada kategori baik; (5) kemampuan kerja sama tim berada pada kategori baik; dan (6) pengembangan diri berada pada kategori sangat baik.
\end{abstract}

\section{Kata Kunci: Kinerja; Alumni; Akreditasi}

Perkembangan pendidikan senantiasa dihadapkan pada sejumlah permasalahan yang belum dapat terpecahkan secara tuntas. Permasalahan pendidikan tersebut adalah: (1) pemerataan pendidikan dan perluasan akses; (2) peningkatan mutu, relevansi dan daya saing; serta (3) penguatan tata kelola; akuntabilitas, dan pencitraan publik. Untuk meningkatkan mutu pendidikan maka perlu melihat dari banyak indikator. Para ahli mengemukakan mengenai faktor penyebab dan solusi mengatasi masih rendahnya mutu pendidikan di Indonesia. Peningkatan mutu dan relevansi pendidikan diukur dari pencapaian kecakapan akademik dan nonakademik yang lebih tinggi yang memungkinkan alumni dapat proaktif terhadap perubahan masyarakat dalam berbagai bidang baik di tingkat lokal, nasional maupun global. Dalam persfektif makro banyak faktor yang mempengaruhi mutu pendidikan, diantaranya faktor kurikulum, kebijakan pendidikan, fasilitas pendidikan, aplikasi teknologi informasi dan komunikasi dalam dunia pendidikan, khususnya dalam kegiatan proses belajar mengajar, aplikasi metode, strategi dan pendekatan pendidikan yang mutakhir dan modern, metode evaluasi pendidikan yang tepat, biaya 
pendidikan yang memadai, manajemen pendidikan yang dilaksanakan secara profesional, sumber daya manusia para pelaku pendidikan yang terlatih, berpengetahuan, berpengalaman dan profesional (Hadis dan Nurhayati, 2010:3).

Untuk meningkatkan mutu pendidikan tersebut maka lembaga pendidikan lebih proaktif dan berkontribusi terhadap penyesaian masalah mutu tersebut. Program Studi S1 Manajemen Pendidikan sebagai salah satu lembaga pendidikan yang memiliki tanggungjawab untuk mendukung peningkatan mutu pendidikan dengan melakukan perubahan. Ini dilakukan untuk memperbaiki kualitas proses pendidikan yang disertai upaya peningkatan relevansinya dalam persaingan global. Oleh karena itu program studi perlu melakukan evaluasi kinerja alumni melalui tracer study yang bertujuan untuk memperoleh masukan-masukan dari para pengguna. Hal sejalan dengan yang dikemukakan oleh Schomburg (2003) bahwa tujuan utama dari kegiatan tracer study adalah untuk mengetahui atau mengidentifikasi kualitas lulusan di dunia kerja, sedangkan tujuan khusus tracer study adalah: (1) mengidentifikasi profil kompetensi dan keterampilan lulusan; (2) mengetahui relevansi dari pelaksanaan kurikulum yang telah diterapkan di perguruan tinggi dengan kebutuhan pasar tenaga kerja dan pengembangan professional di dalam kompetensi jurusan; (3) untuk mengevaluasi hubungan dari kurikulum dan studi di jurusan sebagai pengembangan keilmuan; (4) sebagai kontribusi dalam proses akreditasi jurusan. Sedangkan untuk tujuan tracer study lebih ke arah strategik adalah membuat perencanaan program, pembuatan keputusan, pengambangan profesional, perbaikan program, akuntabilitas dan akreditasi (Halasz \& Behm, 1982). Untuk tujuan yang lebih operasional tracer stady dilakukan untuk mengetahui: (1) sejarah karier alumni; (2) status karier/pekerjaan sekarang; (3) penilaian alumni terhadap program pendidikan atas dasar pengelaman kerja mereka; dan (4) evaluasi oleh pemberi kerja atau sejawat. (Pucel, 1979).

Dengan kegiatan tracer study ini diharapkan memberikan informasi terkait indikasi kekurangan pelaksanaan program studi sehingga mampu menyusun rencana tindak lanjut di masa depan dalam rangka menjamin kualitas pendidikan. Pertanyaan yang dimunculkan dalam kajian ini yang diteliti adalah bagaimana tanggapan pihak pengguna terhadap kinerja alumni dilihat dari: (1) integritas alumni; (2) keahlian sesuai bidang ilmu; (3) kemampuan memanfaatkan teknologi infomasi; (4) kemampuan berkomunikasi; (5) kemampuan kerjasama tim; dan (6) pengembangan diri. Pertanyaan tersebut mengindikasikan bahwa pengetahuan dan keterampilan yang diperoleh alumni di bangku perkuliahan dapat bermanfaat bagi pihak pengguna di tempat tugas.

Pelaksanaan tracer study bagi perguruan tinggi secara keseluruhan adalah sebagai indikator efisiensi eksternal pada institusi perguruan tinggi, dan sebagai dasar untuk menyelengggarakan dialog dengan berbagai kalangan bisnis, industri terkait, dan perguruan tinggi lainnya. Selain itu tracer study dapat dijadikan dasar bagi perguruan tinggi untuk menentukan prioritas, dan pemilihan model pendidikan dan pelatihan yang dapat dikembangkan sesuai dengan karakteristik institusi untuk selanjutnya mengembangkan konsep yang tepat dan memungkinkan dalam implementasi model pendidikan dan pelatihan. tracer study merupakan studi mengenai alumni lembaga penyelenggara pendidikan tinggi, dari hasil tracer study diketahui bahwa waktu tunggu yang relatif lama antara lain disebabkan oleh beberapa faktor, dua hal yang terpenting adalah: (1) kemampuan soft-skill alumni yang kurang memadai dan (2) meningkatnya tingkat persaingan antar pencari kerja yang memiliki kompetensi keahlian/bidang ilmu yang sama.

Hasil penelitian Teichler (1999:169) tentang hubungan perguruan tinggi dan dunia kerja menyarankan bahwa penelitian dibidang ini harus didasarkan pada antisipasi kemungkinan perubahan kondisi dimasa depan misalnya tren ke arah kesulitan atau kemudahan kerja, ke arah banyaknya atau melimpahnya paradigma masyarakat belajar seumur hidup dan ke arah internasional atau pasar tenaga kerja global. Hasil tracer study juga dapat digunakan perguruan tinggi untuk mengetahui keberhasilan proses pendidikan yang telah dilakukan terhadap anak didiknya. Bahkan dalam program hibah kompetisi maupun akreditasi selalu mempersyaratkan adanya data hasil tracer study tersebut melalui parameter masa tunggu lulusan, persen lulusan yang sudah bekerja, dan penghasilan pertama yang diperoleh.

Integrity berasal dari akar kata "integrated", yang berarti berbagai bagian dari karakter dan keterampilan berperan aktif dalam diri kita, yang tampak dari keputusan-keputusan dan tindakan- 
tindakan kita, Integritas melekat dalam tradisi relativisme moral, yang pemahaman tentang perilaku yang dianggap baik bisa bervariasi di antara manusia, budaya, dan zaman. Secara filosofis, relativisme seperti itu tentu saja dapat bertahan, namun paling tidak dalam praktiknya hal itu menjadi hal yang problematis. Dalam definisi ini pembenaran moral dari sudut pandang objektif integritas didasarkan atas kebenaran universal ketimbang sekadar setuju atas serangkaian pandangan moral dan nilai-nilai individu atau kelompok. Penilaian terhadap integritas tidak bisa hanya didasarkan pada tolok ukur yang digunakan oleh masing-masing individu atau kelompok atau budaya saja. Ada bahaya ketika suatu perilaku individu yang sesungguhnya sangat dicela oleh banyak orang, tetap ada saja orang atau kelompok atau budaya tertentu yang menganggapnya sebagai hal yang terpuji. Relativisme moral seperti ini tidak dapat dipertahankan. Sesuatu yang dianggap baik itu harus bisa dibuka dan tahan uji atas penilaian masyarakat umum.

Integritas merupakan sebuah standar moralitas dan etika seseorang, tidak ada hubungannya dengan situasi yang kebetulan ada di sekitar dan tidak mendorong kecepatan. Konsep integritas itu sendiri di dalamnya mengidentikkan dengan kata hati, akuntabilitas moral, komitmen moral, dan konsistensi moral seseorang (Paine, 1994) .Tanpa adanya kompetensi maka sulit untuk menunjukkan integritas itu sendiri, sementara kompetensi sendiri akan sulit berwujud kinerja baik tanpa disertai bagian-bagian dari karakter, yang mendorongnya untuk bisa mencapai hasil yang baik dan dengan cara yang baik. Integritas di tempat kerja tidak bisa dilepaskan dari bagamana seharusnya kompetensi yang dimiliki oleh seseorang untuk bisa menghasilkan kinerja baik di tempat kerja. (Lee, 2006:20, Becker T, 1998:154, Simon, 2007:650). Integritas merupakan konsep formulasi makro yang mencakup kumpulan nilai kebajikan, integritas mengacu pada hubungan diantara serangkain/suatu set nilai moral, dimana nilai moral ini konsisten dengan serangkan/satu set dengan nilai sosial, dan integritas lebih jauh membutuhkan keselarasan antara perilaku dengan serangkan/satu set nilai moral/sosial disepanjang waktu dan berbagai konteks sosial (Dunn, 2009 dalam Zainuri dkk :2017)

Kinerja berarti pencapaian/prestasi seseorang berkenan dengan tugas yang diberikan kepadanya. Hasil kerja yang dapat dicapai oleh seseorang atau sekelompok orang dalam suatu organisasi sesuai dengan wewenang dan tanggung jawab masing-masing, dalam upaya mencapai tujuan organisasi bersangkutan secara legal, tidak melanggar hukum dan sesuai dengan moral etika (Sedarmayanti 2007:260). Keterampilan kerja karyawan dalam konteks ini dapat diukur dengan beberapa indikator seperti (a) menentukan cara menyelesaikan tugas pekerjaan; (b) menentukan prosedur terbaik dalam melaksanakan pekerjaan; (c) menyelesaikan tugas dengan baik; (d) menentukan volume tugas terbaik yang dapat diselesaikan; (e) menentukan ukuran kualitas pekerjaan terbaik yang dapat diselesaikan; (f) memprediksi hasil pelaksanaan pekerjaan. (4) sikap merupakan pondasi terpenting yang menentukan tingkat keberhasilan seseorang (Sudaryono, 2014:214). Sikap adalah evaluasi, perasaan dan kecenderungan seseorang yang relatif konsisten terhadap suatu objek atau gagasan, dengan kata lain bahwa sikap adalah suatu perasaan yang timbul pada diri seseorang terhadap suatu objek, baik sebelum dan sesudah orang melihat, merasakan, dan menikmati objek tersebut menurut (Sunyoto, $2015: 42$ ).

Penggunaan teknologi informasi menyebabkan semakin terbuka dan tersebarnya informasi dan pengetahuan dari dan ke seluruh dunia menembus batas, jarak, tempat, ruang, dan waktu. Pengaruh penggunaan teknologi informasi meluas ke berbagai kehidupan, termasuk bidang pendidikan (Munawaroh, 2012:1). Teknologi informasi merupakan seperangkat alat yang membantu bekerja dengan informasi dan melakukan tugas yang berhubungan dengan pemrosesan informasi. Hal ini dijelaskan bahwa teknologi informasi merupakan suatu gabungan antara teknologi komputer dan teknologi komunikasi. Teknologi yang memanfaatkan komputer sebagai perangkat utama untuk mengolah data menjadi informasi yang bermanfaat. Teknologi komputer merupakan seperangkat peralatan yang digunakan untuk mengubah data menjadi suatu informasi yang dapat menjadi bahan dalam pengambilan keputusan. Sedangkan kegunaan utama teknologi informasi secara global adalah membantu dalam pemecahan masalah dengan kreatifitas tinggi dan membuat manusia semakin efektif dalam memanfaatkannya. (Kadir dan Triwahyuni 2003:2, Fauzi 2008:5). Konsep kinerjanya adalah kuantitas, kualitas dan ketepatan waktu dalam menyelesaikan pekerjaan oleh karyawan. Bila para karyawan dapat menggunakan teknologi informasi yang ada, maka hal ini akan dapat meningkatkan kinerja karyawan. 
Hubungan antara teknologi informasi dengan kinerja dikemukakan oleh Tjhai (2003:8) agar suatu teknologi informasi dapat memberikan dampak yang positif terhadap kinerja individual, maka teknologi informasi tersebut harus dimanfaatkan dengan tepat dan harus mempunyai kecocokan dengan tugas yang didukung.

Menurut Rowley (2002:58) bahwa kemampuan komunikasi adalah kemampuan untuk mengirim pesan-pesan yang mendukung pencapaian tujuan dimana tetap menjaga penerimaan sosial. Kemampuan komunikasi merupakan peran penting yang harus dimiliki seorang karyawan dalam proses komunikasi, baik dalam penyampaian informasi, memecahkan permasalahan, maupun dalam pemberian umpan balik. Sedangkan menurut Payne (2005:38) bahwa indikator pengukur kemampuan komunikasi adalah motivasi komunikasi, pengetahuan komunikasi, dan keterampilan komunikasi. Luthan (2011:24) memberikan pengertian yang secara langsung mengarah pada perubahan dan perkembangan organisasi yang hanya dapat terjadi melalui pengembangan sumber daya manusia di lingkungan masing-masing. Untuk mencapai tujuan organisasi maka diperlukan sebuah komunikasi yang baik, di mana terdapat jalinan pengertian dalam komunikasi tersebut sehingga dapat dimengerti serta dilaksanakan antara pihak yang satu dengan pihak yang lain, komunikasi ini sangat berperan dalam suatu organisasi untuk mencapai tujuannya.

Kerjasama tim diperlukan untuk mewujudkan keberhasilan kerja. Kerjasama tim akan menyatukan kekuatan ide-ide yang akan mengantarkan pada kesuksesan. Setiap orang yang bekerja di suatu organiasasi harus mampu bekerja dalam sebuah tim, agar sebuah tim dapat berjalan dengan baik, diperlukan adanya kepercayaan, ketulusan, totalitas, kekompakan, keadilan, saling memahami, kebersamaan, toleransi, dan kerjasama. Menurut Warsihna, (2010:9). tim kerja merupakan kelompok yang upaya-upaya individualnya menghasilkan suatu kinerja yang lebih besar dan tinggi daripada jumlah dari masukan individu-individu. Hal ini memiliki pengertian bahwa kinerja yang dicapai oleh sebuah tim lebih baik dari pada kinerja per-individu di suatu organisasi ataupun suatu perusahaan. (Sopiah, Robbins dan Judge:2008).

Pengembangan diri merupakan pengembangan segala potensi yang ada pada diri sendiri, dalam usaha meningkatkan potensi berfikir dan berprakarsa serta meningkatkan kapasitas intelektual yang diperoleh dengan jalan melakukan berbagai aktivitas. Menurut Sastrohadiwiryo (2005:199) bahwa pendidikan dan pelatihan di dalam suatu organisasi merupakan tugas untuk meningkatkan pengetahuan, pengertian atau sikap tenaga kerja sehingga mereka dapat lebih menyesuaikan diri dengan lingkungan kerja mereka." Sedangkan menurut Mangkuprawira (2002:135) bahwa: "Pelatihan adalah sebuah proses mengajarkan pengetahuan dan keahlian tertentu serta sikap agar karyawan semakin terampil dan mampu melaksanakan tanggung jawab dengan semakin baik, sesuai dengan standar".

Jackson (2002: 44) mengemukakan bahwa pengembangan merupakan pertumbuhan kemampuan yang terjadi jauh melampaui apa-apa yang dituntut dalam suatu pekerjaan. Hal ini mewakili usaha-usaha untuk meningkatkan kemampuan karyawan untuk menangani berbagai jenis penugasan. Pengembangan ini dilakukan untuk menambah pengetahuan dan keahlian ataupun keterampilan mereka sehingga dapat menunjang adanya kesempatan dalam promosi karyawan. Setiap pimpinan perusahaan perlu melakukan pengembangan sumber daya manusia, sebab melalui pengembangan ini perusahaan akan mempunyai tenaga kerja yang terampil dan cakap, dengan demikian tujuan perusahaan dapat terealisasikan dengan baik. Melalui pelatihan dan pengembangan, karyawan dapat terbantu mengerjakan dan menyelesaikan pekerjaan yang ada, dapat meningkatkan keseluruhan karier karyawan dan dapat membantu mengembangkan tanggung jawabnya pada saat ini maupun di masa mendatang. sehingga ada beberapa alasan mengapa pelatihan dan pengembangan harus dilakukan atau menjadi bagian yang sangat penting dari kegiatan manajemen sumber daya manusia.

\section{METODE}

Penelitian ini dilaksanakan di Kabupaten Gorontalo dengan menggunakan pendekatan kuantitatif, subyek penelitian ini adalah alumni dan pengguna alumni yang terjangkau dan tersebar di Kabupaten Gorontalo yang berjumlah 40 orang. Indikator kajian ini adalah: (1) integritas alumni; (2) keahlian 
sesuai bidang ilmu; (3) kemampuan memanfaatkan teknologi infomasi; (4) kemampuan komunikasi; (5) kerja sama tim; dan (6) pengembangan diri. Sedangkan data yang dikumpul dengan menggunakan: kuensioner, wawancara, dan dokumentasi. Analisis data menggunakan analisis deskriptif peresentase kemudian digambarkan dalam bentuk tabel frekuensi.

\section{HASIL DAN PEMBAHASAN}

Dalam kajian ini akan dibahas tentang: (1) integritas alumni; (2) keahlian alumni sesuai bidang ilmu; (3) kemampuan memanfaatkan teknologi informasi; (4) kemampuan berkomunikasi; (5) kemampuan kerja sama tim; dan (6) pengembangan diri. Untuk lebih terperinci akan dibahas sebagai berikut:

\section{Integritas Alumni}

Indikator integritas yang terdiri dari tiga pernyataan yaitu: (1) kejujuran dengan perolehan skor $85 \%$ termasuk kriteria baik; (2) konsistensi dengan perolehan skor 92\% termasuk kriteria sangat baik; dan (3) keberanian dengan perolehan skor $82 \%$ termasuk kriteria baik. Berdasarkan hasil capaian tersebut maka dapat dikemukakan bahwa integritas alumni di Kabupaten Gorontalo dikategorikan baik ini dilihat dari rata-rata skor capaian $86 \%$.

Berdasarkan hasil persentase, integritas berada pada kategori baik dengan presentase $86 \%$ yang diuraikan dalam tiga sub indikator yaitu kejujuran dengan nilai $85 \%$ berada pada kategori baik, konsistensi dengan nilai persentase 92\% dengan kategori sangat baik, keberanian dengan nilai persentase $82 \%$ dengan kriteria baik. Alumni manajemen pendidikan memiliki kepercayaan diri yang sangat tinggi dalam mengerjakan setiap pekerjaan yang tugaskan kepada alumni, kepercayaan diri sebagaimana yang diungkapkan oleh Lauter (2002:4) kepercayaan diri merupakan suatu sikap atau keyakinan atas kemampuan diri sendiri sehingga dalam tindakan-tindakannya tidak terlalu cemas, merasa bebas untuk melakukan hal-hal yang sesuai keinginan dan tanggung jawab atas perbuatannya, sopan dalam berinteraksi dengan orang lain, memiliki dorongan prestasi serta dapat mengenal kelebihan dan kekurangan diri sendiri. Integritas merujuk pada sifat layak dipercaya dalam diri seorang manusia di dalamnya terdapat kualitas-kualitas individu seperti karakter jujur sebagaimana menurut Tabrin (2006:25) jujur adalah perkataan dan perbuatan sesuai dengan kebenaranatau kenyataan, dan jujur merupakan induk dari sifat-sifat terpujian. Seseorang dikatakan berintegritas, jika seseorang/institusi tersebut ketika melakukan tindakan konsisten sesuai dengan nilai, tujuan dan tugas yang diemban oleh seseorang/institusi tersebut, (Brown, et al, 2005 dalam Zainuri dkk ,2017).

\section{Keahlian Sesuai Bidang Ilmu}

Indikator keahlian sesuai bidang ilmu yang terdiri dari empat pernyataan yakni: (1) pengetahuan dengan capaian persentase $82 \%$ termasuk kategori baik; (2) keahlian dengan capaian $84 \%$ termasuk kategori baik; (3) keterampilan dengan persentase $85 \%$ termasuk kategori baik; dan (4) sikap dengan persentase capaian $81 \%$ termasuk kategori baik. Berdasarkan persentase indikator keahlian berdasarkan bidang ilmu alumni perolehan skor tertinggi $85 \%$ dengan kriteria baik yaitu keterampilan, namun perolehan skor terendah dengan perolehan $81 \%$ dengan kriteria baik yaitu sikap. Dengan demikian capaian persentasi untuk indikator sesuai bidang ahli termasuk kategori baik dengan nilai rata-rata skor capaian $83 \%$.

Berdasarkan hasil persentase keahlian berdasarkan bidang ilmu berada pada kategori baik dengan nilai presentase $83 \%$ yaitu dengan empat sub indikator pengetahuan dengan nilai presentase $82 \%$ kategori baik, keahlian dengan nilai presentase $84 \%$ kategori baik, keterampilan dengan nilai presentase $85 \%$ kategori baik, dan sikap dengan nilai presentase $81 \%$ kategori baik. Alumni mengembangkan keahlian berdasarkan bidang ahli atau profesionalisme untuk mengembangkan strategi-strategi untuk instansi tempat alumni berkerja sebagaimana yang di jelaskan oleh Sururi (2002:2) bahwa dengan profesionalisme akan menunjukkan komitmen para anggota suatu profesi untuk meningkatkan kemampuan profesionalnya dan terus-menerus mengembangkan strategi-strategi yang digunakannya dalam melakukan pekerjaan yang sesuai dengan profesinya. Profesi setiap alumni mempunyai karakteristik yang berbeda-beda dengan berbagai latar belakang pekerjaan misalnya ada sebagai guru, 
karyawan serta bekerja diswasta. Sebagai seorang guru tentu dibutuhkan kemampuan profesional karena sangat memegang peranan penting. Kemampuan profesional tersebut meliputi 4 (empat) aspek, yaitu: (a) kemampuan merencanakan program belajar mengajar; (b) kemampuan melaksanakan dan memimpin/ mengelola proses belajar mengajar; (c) kemampuan menilai kemajuan proses belajar mengajar; dan (d) kemampuan menguasai bahan pelajaran, dalam arti menguasai bidang studi atau mata pelajaran yang dipegangnya. Seorang guru tidak dapat dikatakan guru berkualifikasi profesional tanpa penguasaan keempat aspek tersebut. Hasil penelitian khususnya alumni-alumni yang berprofesi sebagai guru tentunya mempunyai kriteria-kriteria yang menjadikan alumni sebagai guru yang profesioanal. Kemampuan dari siswa-siswa dengan menilai hasil pembelajaran dari siswa-siswa karena hasil pembelajaran yang rendah akan diberikan arahan oleh guru agar siswa yang memperoleh hasil pembelajaran yang lebih baik. Pengedalian emosi bertujuan agar siswa-siswa tidak merasaa tertekan dalam pembelajaran karena emosi berpengaruh pada kegiatan-kegiatan sehari-hari seperi yang dikemukakan Baharuddin (2009:55) bahwa emosi akan membawa pengalaman yang sadar mempengaruhi kegiatan jasmani dan afektif (meliputi unsur-unsur perasaan) yang mengikuti keadaan fisiologis dan mental yang muncul dan penyesuaian batiniah dan yang mengekspresikan dirinya dalam tingkah laku yang tampak".

\section{Kemampuan Memanfaatkan Teknologi Informasi}

Indikator kemampuan alumni dalam menggunakan teknologi informasi yang terdiri dari 8 pernyataan yaitu: (1) kemampuan alumni beradaptasi teknologi baru dengan perolehan skor $79 \%$ termasuk kriteria cukup baik; (2) kemampuan penguasaan teknologi dari alumni dengan skor $80 \%$ dengan kriteria baik; (3) alumni memiliki kemampuan dalam mengendalikan komputer dengan perolehan skor $80 \%$ dengan kriteria baik; (4) alumni memiliki kemampuan menggunakan internet dengan capaian skor $81,6 \%$ dengan kiteria baik; (5) alumni mampu memanfaatkan teknologi untuk meningkatkan mutu pembelajaran dengan perolehan skor 76,6\% dengan kriteria cukup baik; (6) kemampuan alumni menggunakan teknologi informasi dalam meningkatkan kualitas waktu dalam menyelesaikan pekerjaan dengan perolehan skor 87,5\% dengan kriteria baik; (7) kinerja alumni menggunakaan teknologi informasi dalam menghasilkan pekerjaan yang positif dengan perolehan skor $75 \%$ dengan kriteria cukup baik; dan (8) inerja alumni secara individu dengan menggunakan teknologi informasi dimanfaatkan dengan tepat dengan perolehan skor $76,6 \%$ dengan kriteria cukup baik. Skor rata-rata yang dicapai indicator kemampuan alumni menggunakan teknologi yaitu $80,0 \%$ termasuk kriteria baik.

Berdasarkan hasil persentase teknologi informasi berada pada kategori baik dengan nilai persentase $80 \%$. Penggunaan teknologi informasi menyebabkan semakin terbuka dan tersebarnya informasi dan pengetahuan dari dan ke seluruh dunia menembus batas, jarak, tempat, ruang, dan waktu. Seperti yang dijelaskan oleh Munir (2008: 9-10), memberikan makna bahwa teknologi informasi tidak terbatas pada teknologi komputer yang digunakan untuk memproses dan menyimpan informasi, melainkan juga mencakup teknologi komunikasi untuk mengirimkan informasi perbedaannya, teknologi informasi lebih mengarah pada sistem pengolahan informasi, sedangkan teknologi komunikasi berfungsi untuk pengiriman informasi. Pengaruh penggunaan teknologi informasi meluas ke berbagai kehidupan, termasuk bidang pendidikan. Penggunaan teknologi sebagai alat untuk mempermudah alumni yang berada di Kabupaten Gorontalo dalam memperoleh informasi atau berbagi informasi namun pada masingmasing bidang, suatu teknologi informasi memiliki manfaat tersendiri dilihat dari bidang pendidikan teknologi informasi memiliki pengaruh paling besar terhadap bidang pendidikan. Hal ini dikarenakan fungsi utama dalam pendidikan adalah sebagai sarana saling bertukar informasi baik untuk anak-anak maupun guru. Untuk lebih memperdalam ilmu pengetahuan alumni yang berada di Kabupaten Gorontalo juga bisa karena tidak ada batas usia untuk selalu belajar setiap saat. Seperti yang telah di jelaskan Munawaroh (2012:1), Integrasi penggunaan teknologi informasi dan komunikasi ke dalam pembelajaran adalah untuk meningkatkan kompetensi guru dalam mengajar dan meningkatkan mutu belajar bagi peserta didik. Teknologi informasi dan komunikasi yang sifatnya inovatif dapat meningkatkan apa yang sedang dilakukan sekarang serta apa yang belum dilakukan tetapi akan dilakukan dengan menggunakan teknologi informasi dan komunikasi. 


\section{Kemampuan Komunikasi}

Indikator kemampuan alumni dalam berkomunikasi terdiri dari dua pernyataan yaitu: (1) kemampuan kemunikasi dari dari atas kebawah dengan perolehan skor 86\% dengan kriteria baik, dan (2) kemampuan berkomunikasi dari bawah ke atas dengan perolehan skor 78\% dengan kriteria baik. Persentase rata-rata capaian indikator kemampuan alumni dalam berkomunikasi yaitu $82 \%$ termasuk kriteria baik.

Kemampuan alumni pada tahap komunikasi ini, alumni sudah baik penilaian dilihat dari hasil persentase $82 \%$ dengan kriteria baik, yang diuraikan dengan dua sub indikator yaitu komunikasi dari atasan kebawahan mencapai hasil persentase $86 \%$ dengan kriteria baik, dan komunikasi dari bawahan ke atasan mencapai hasil presentase $78 \%$ dengan kriteria baik. Komunikasi yang dilakukan oleh alumni sudah baik dilihat dari penyampaian pesan dan pendapat yang dikomunikasikan alumni dengan pimpinan, pemimpin selalu menciptakan hubungan yang baik dengan alumni, begitupun sebaliknya dengan alumni. Komunikasi antara pemimpin dan alumni dalam menciptakan hubungan yang baik dalam organisasi yaitu dengan menggunakan komunikasi antar personal yaitu komunikasi yang terjadi antar komunikator dengan komunikan secara langsung dengan cara berhadapan muka atau tidak. Komunikasi seperti ini lebih efektif karena kedua belah pihak saling melancarkan komunikasinya dan dengan feedback keduanya melaksanakan fungsi masing-masing. Untuk itu pemimpin harus mampu menyediakan waktu untuk dapat berbincang dengan para alumni, sekaligus mengatasi kendala-kendala yang menjadi pemicu keterlambatan dalam penyelesaian tugas. Hal ini juga akan memunculkan berbagai tanggapan dari alumni, yang harus diterima oleh pemimpin organisasi. Hal ini juga di sampaikan oleh (Susanto 1980, Wursanto 2001), bahwa komunikasi mempunyai arti penting dalam mendukung pencapain tujuan organisasi.

\section{Kemampuan Kerja Sama Tim}

Indikator alumni mengenai kemampuan bekerja sama secara tim yang terdiri dari sepuluh pernyataan yaitu: (1) kemampuan alumni dalam bekerja dalam tim dengan perolehan skor 92,5\% dengan kriteria sangat baik, (2) alumni mampu menjalankan hubungan sosial dengan perolehan skor 85,8\% dengan kriteria baik, (3) alumni mampu menghasilkan kinerja yang memuaskan dengan perolehan skor 83,3\% dengan kriteria baik, (4) alumni mampu memperlihatkan kualitas yang lebih tinggi dengan berkerja secara tim dengan perolehan skor 79,1\% dengan kriteria cukup baik, (5) Kemampuan alumni dalam menghasilkan sinergi positif melalui usaha yang kerkoordinasi dengan perolehan skor $80,8 \%$ dengan kriteria baik, (6) alumni memperlihatkan kepercayaan diri dengan perolehan skor 96,6\% dengan kriteria sangat baik, (7) alumni mampu mengembangkan menajemen proyek/program dengan perolehan skor $78,3 \%$ dengan kriteria cukup baik, (8) alumni mampu menciptakan interaksi antara alumni dengan perolehan skor $78,3 \%$ dengan kriteria cukup baik, (9) alumni pandai mengorganisasikan diri sendiri dengan tim dengan perolehan skor $82,5 \%$ dengan kriteria baik, dan (10) alumni mampu membangun hubungan baik dengan tim dengan perolehan skor $86,6 \%$ dengan kriteria baik. Skor rata-rata yang mencapai pada indikator alumni dapat bekerja secara tim dengan capain sebesar $84 \%$ dengan kriteria baik.

Berdasarkan hasil indikator yang hanya memiliki satu sub indikator persentase yaitu tim kerjasama dengan mencapai nilai persentase $84 \%$ dengan kriteria baik. Di setiap instansi alumni miliki kinerja yang baik meski tidak sesuai dengan bidang ahlinya masing-masing tetapi alumni mampu memberikan hasil kerja yang baik untuk meningkatkan kualitas disetiap instansi, dan hal ini juga dilihat dari kerja sama alumni dengan keryawan-karyawan lainnya. Kerjasama tim yang dilakukan setiap alumni untuk mewujudkan keberhasilan kerja. Setiap alumni yang bekerja di suatu sekolah merupakan bekerja dalam sebuah tim. Agar sebuah tim dapat berjalan dengan baik. Adanya kemampuan kerjasama tim yang baik pada alumni menunjukkan komitmen yang tinggi alumni pada pekerjaannya. Kerjasama merupakan proses sosial, dimana didalamnya terdapat aktivitas yang menyatukan kekuatan ide-ide tertentu yang ditunjukkan untuk mencapai tujuan bersama diperlukan adanya kepercayaan, ketulusan, totalitas, kekompakan, keadilan, saling memahami, kebersamaan, toleransi, kerjasama dengan saling membantu dan saling memahami aktivitas masing-masing. (Warsihna 2016:9, Abdulsyani, 1994:156). 


\section{Pengembangan Diri}

Indikator pengembangan diri yang berkaitan dengan pembinaan dan pelatihan, indikator ini terdiri dari tujuh pernyataan yaitu: (1) alumni memiliki daya juang yang baik dengan perolehan skor 79,1\% dengan kriteria cukup baik; (2) alumni memiliki kedisiplinan dengan perolehan skor 86,6\% dengan kriteria baik; (3) alumni memiliki motivasi yang tinggi dengan perolehan skor 83,3\% dengan kriteria baik; (4) kemampuan alumni dalam mengembangkan segala potensi yang ada pada diri alumni dengan perolehan skor $85 \%$ dengan kriteria baik; (5) kemampuan alumni dalam meningkatkan potensi yang ada pada dirinya dengan perolehan skor $95 \%$ dengan kriteria sangat baik; (6) kemampuan alumni dalam meningkatkan rasa percaya diri dengan perolehan skor 84,1\% dengan kriteria baik; (7) kemampuan dan keinginan untuk terus belajar sepanjang hayat dengan perolehan skor $84,1 \%$ dengan kriteria baik. Skor rata-rata indikator pengembangan diri mencapai 90\% dengan kriteria sangat baik.

Berikut ini dikemukakan kesimpulan kinerja alumni yaitu: (1) integritas alumni perolehan skor 86\% dengan kriteria baik; (2) keahlian sesuai bidang ilmu perolehan skor 83\% dengan kriteria baik; (3) Kemampuan memanfaatkan teknologi informasi perolehan skor $80 \%$ dengan kriteria baik; (4) mampu berkomunikasi memperoleh skor $82 \%$ dengan kriteria baik; (5) mampu bekerja kerja dalam tim perolehan skor $84 \%$ dengan kriteria baik; (6) pengembangan diri perolehan skor $90 \%$ dengan kriteria sangat baik. Untuk persentase capaian skor rata-rata kinerja alumni Program Studi Manajemen Pendidikan di Kabupaten Gorontalo mencapai 84\% dengan kriteria baik. Untuk perolehan nilai tertinggi diperoleh pada indikator pembinaan/pelatihan dalam pengembangan diri capaian $90 \%$ kategori sangat baik, dan nilai terendah diperoleh pada indikator penggunaan teknologi dengan persetase $80 \%$ termasuk kategori baik. Berdasarkan hasil indikator yang hanya memiliki satu sub indikator persentase yaitu pengembangan diri mencapai nilai persentase $90 \%$ dengan kriteria sangat baik. Pengembangan diri adalah tanggung jawab setiap alumni pribadi. Alumni dapat memanfaatkan dukungan yang dapat diberikan oleh kantor ataupun manager alumni, tetapi keberhasilan pengembangan diri yang alumni lakukan terletak kepada diri alumni pribadi, kemampuan alumni, dan usaha alumni. Dan ini berarti bahwa alumni harus berani mengambil tanggung jawab dalam mengembangkan keterampilan, meningkatkan kinerja dan kemajuan karir alumni. Pengembangan diri yang dimaksud adalah pengembangan segala potensi yang ada pada diri sendiri, meningkatkan rasa percaya diri dalam usaha meningkatkan potensi berfikir dan berprakarsa serta meningkatkan kapasitas intelektual yang diperoleh dengan jalan melakukan berbagai aktivitas. (Fanani 2003:3 dan Tarmudji:1998:29). Untuk lebih memperjelas kinerja alumni dapat dilihat pada gambar berikut:

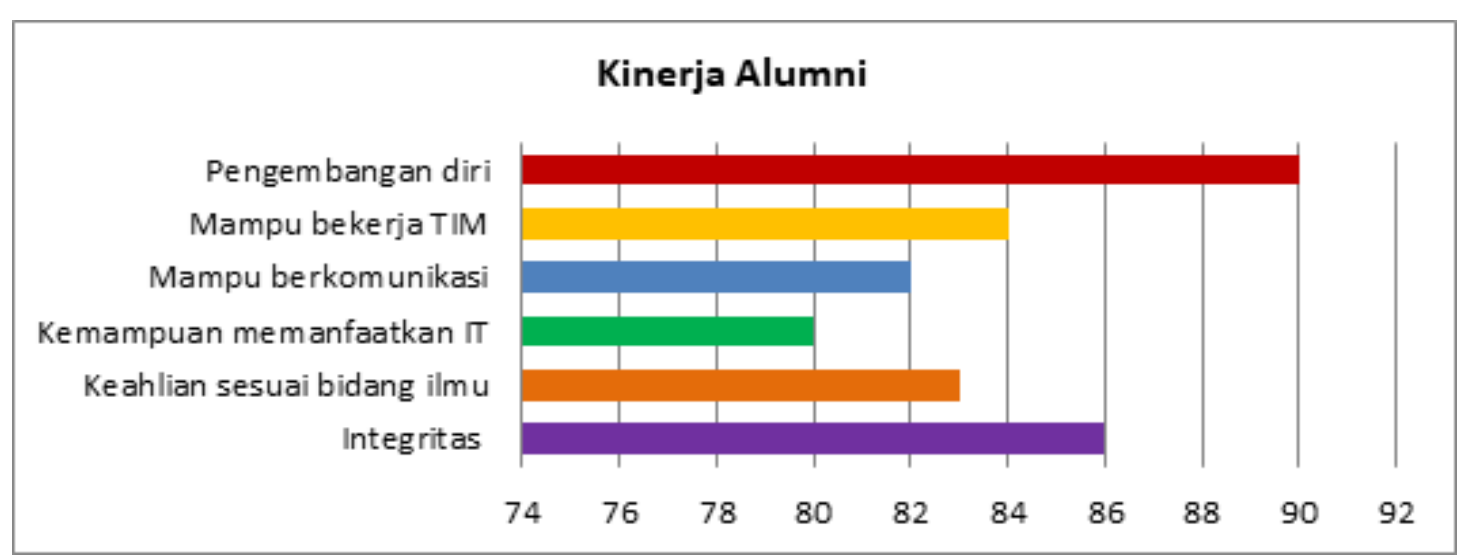

Gambar 1. Rangkuman kinerja alumni 


\section{SIMPULAN}

\section{Simpulan}

Berdasarkan hasil penelitian, maka kinerja alumni Program Studi Manajemen Pendidikan dapat disimpulkan sebagai berikut: (1) kepuasan pengguna alumni terhadap integritas berada pada kategori baik. Hal ini di karenakan alumni menunjukkan bahwa alumni mempunyai karakter yang baik termasuk etika dan moral; (2) kepuasan pengguna alumni terhadap keahlian sesuai bidang ilmu berada pada kategori baik, ini disebabkan karena ada beberapa alumni yang berprofesi sebagai guru menguasai kompetensi yang dibutuhkan sebagai seorang guru, dan berapa berprofesi sebagai karyawan mampu menyesuaikan diri di tempat kerja mereka; (3) kepuasan pengguna alumni terhadap kemampuan menggunakan teknologi informasi berada pada kategori baik. Hal ini di karenakan alumni telah menguasai dan mampu memanfaatkan teknologi informasi; (4) kepuasan pengguna alumni terhadap aspek kemampun berkomunikasi berada pada kategori baik. Hal ini di karenakan alumni mampu berkomunikasi dengan baik terhadap berbagai pihak; (5) kepuasan pengguna alumni terhadap kemampuan kerja sama tim berada pada kategori baik. Hal ini di karenakan alumni dapat bekerja dalam tim serta memiliki komitmen yang tinggi terhadap pekerjaannya; (6) kepuasan pengguna alumni terhadap pengembangan diri berada pada kategori sangat baik. Hal ini karenakan alumni melakukan pengembangan diri baik atas inisiatif sendiri maupun atas perintah kantor.

\section{Saran}

Hasil kajian ini menyarankan kepada: (1) pihak jurusan melakukan evaluasi secara berkala tentang kinerja alumni dengan melibatkan pihak pengguna; (2) pihak jurusan perlu melakukan review dan peninjauan kurikulum menyesuaikan dengan kebutuhan dunia kerja; (3) alumni agar lebih menggembangkan kemampuan dirinya terutama kemampuan yang berkaitan dengan communication skill, kemampuan menggunakan teknologi informasi; (4) pihak pengguna alumni agar intens menjalin komunikasi dengan pihak jurusan sebagai penyedia tenaga kerja dan memberikan masukan-masukan kemampuan apa yang dibutuhkan di kantor atau lembaga mereka.

\section{DAFTAR RUJUKAN}

Abdulsyani. 1994. Sosiologi Skematika Teori dan Terapan. Jakarta: Bumi Aksara.

Astrid, S. 1980. Komunikasi Massa. Bandung: Bina Cipta.

Baharuddin. 2009. Pendidikan \& Psikologi Perkembangan. Jogjakarta: Ar-Ruzz Media.

Becker, T. 1998. Integrityin Organization: Beyond Honesty And Conscienstiousness. Academic of Management Review.

Fanani, A.C. 2003. Studi tentang Metode Belajar Mahasiswa Pendidikan Agama Islam dalam Upaya Pengembangan Diri di Fakultas Tarbiyah IAIN Sunan Ampel Surabaya Periode 2000-2002. Jurnal Fakultas Tarbiyah Uin Sunan Ampel Surabaya.

Fauzi, A. 2008. Pengantar Teknologi Informasi. Yogyakarta: Graha Ilmu.

Hadis, A. dan Nurhayati. 2010. Manajemen Mutu Pendidikan. Bandung: Penerbit

Alfabeta.

Halasz, I., \& Behm, K. 1982. Evaluating Vocational Education Programs. A Handbook for Corrections Educators. Research and Development Series No. 227. National Center for Research in Vocational Education. National Center Publications, Box F, 1960 Kenny Rd., Columbus, OH 43210.

Kadir, A.dan Triwahyuni, T. 2003. Pengendalian Informasi. Yokyakarta: Andi.

Lee, S. A. 2006. Authentic Leadership And Behavioral Integrity As Drivers Of Follower Commitment and Performance. Journal of Financial Planning. 19 (8).

Luthan, F. 2011. Organizational Behavior. Twelfth Edition Ny: Mcgraw- Hill/Irwin.

Mangkuprawira, S. 2002. Manajemen Sumber Daya Manusia Strategi. Jakarta: Ghalia Indonesia.

Mathis L. R. \& John. H. J. 2002. Sumber Daya Manusia. Jakarta: PT. Salemba Empat.

Munawaroh, I. 2012. Pemanfaatan Teknologi Informasi dan Komunikasi untuk Menumbuhkan Kreativitas dan Kemandirian Belajar Pusat Teknologi Informasi \& Komunikasi Pendidikan. 
Munir. 2008. Kurikulum Berbasis Teknologi Informasi dan Komunikasi. Bandung: Alfabeta.

Paine. 1994. Managing for Organizational Integrity.

Payne, H.J. 2005. Reconceptualizing Social Skills In Organizations: Exploring the Relationship Between Communication Competence. Job Performance and. Supervisory Roles. Journal of Leadership \& Organizational Studies.

Peter, L. 2002. Tes Kepribadian (Alih Bahasa: D.H Gulo). Edisi Bahasa Indonesia. Cetakan Ketigabelas. Jakarta: Bumi Aksara.

Pucel, D. J. 1972. The Wilms Study: Analysis of Methodology. Journal of Vocational Education Research, 1(1), 3-10, Win 76 .

Robbins, S. P. J. \& Timothy, A. 2008. Perilaku Organisasi. Edisi Kedua Belas. Jakarta: Salemba Empat.

Rowley, R. D. 2002. Communication Competence: the Essence of Aligning Action. Retrieved 22, Mei 2018 From $\mathrm{http}: / /$ www.algningaction.com/comcomp.html.

Rusyan, T. 2006. Pendidikan Budi Pekerti. Jakarta: Inti Media Cipta Nusantara.

Sastrohadiwiryo, S. 2005. Manajemen Tenaga Kerja Indonesia Pendekatan Admini Stratif dan Operasional. Jakarta: PT. Bumi Aksara.

Schomburg, H. 2003. Handbook for Graduate Tracer Study. Moenchebergstrasse Kassel, Germany: Wissenschaftliches Zentrum Für Berufs-Und Hochschulforschung, Universitat Kassel.

Sedarmayanti, 2007. Manajemen Sumber Daya Manusia. Bandung. PT. Refika Aditama.

Simons, T. L., Friedman, R., Liu, L. A., \& Mclean-Parks, J. 2007. Racial DifferencesIn Sensitivity To Behavioral Integrity: Attitudinal Consequences, In-Group Effects, and "Trickle Down" Among Black And Non-Black Employees. Journal Of Applied Psycholog.

Sopiah, 2008. Perilaku Organisasi. Edisi Pertama. Yogyakarta: Andi.

Sudaryono. 2014. Budaya \& Perilaku Organisasi, Edisi Pertama. Jakarta: Lentera Ilmu

Cendekia

Sunyoto, D. 2015. Penelitian Sumber Daya Manusia. PT. Buku Seru.

Sururi. 2002. Pengembangan Visi Sekolah: Meningkatkan Profesionalisasi Guru dan Kepala Sekolah. Jurnal. Tanggal 03 April 2018

Tarmudji, T. 1998. Pengembangan Diri. Yogyakarta: Liberty Yogyakarta

Teichler, U. 1999. Research on the Relationship Between Higher Education and the World of Work: Past Achievements, Problems and New Challenges. Printed in the Netherland: Kluwer Academic Publisher.

Tjhai F. J. 2003. Analisis Faktor Faktor yang Mempengaruhi Pemanfaatan Teknologi Informasi Terhadap Kinerja Akuntan Publik. Jurnal Bisnis dan Akuntasi.

Warsihna, J. 2016. Modul Pelatihan Budaya Kerja \& Kerjasama Tim. Kemdikbud: Pusat Teknologi Informasi \& Komunikasi Pendidikan. Jakarta.

Wursanto. 2001. Ilmu Komunikasi Teori dan Praktik. Yogyakarta: Kanisius

Zainuri, M., dkk. 2017. Konsepsi Integritas (Modul Diseminasi Gugus Depan Integritas Tahun 2017). Pemerintah Provinsi Riau. 